\title{
Ayaktan takip ve tedavi edilen erişkin hastalarda akılcı antibiyotik kullanımı
}

\author{
Rational use of antibiotics in adult patients treated in the outpatient setting \\ Mustafa Gökhan Gözel* \\ İnfeksiyon Hastalıkları ve Klinik Mikrobiyoloji Anabilim Dalı (Yrd. Doç. Dr. M. G. Gözel), \\ Cumhuriyet Üniversitesi Tıp Fakültesi, TR-58140 Sivas
}

\section{Özet}

Sistemik antibiyotiklerin önemli bir kısmı ayaktan başvuran ve poliklinik şartlarında takip ve tedavi edilen hastalarda kullanılmaktadır. Özellikle üst solunum yolu infeksiyonları gibi sıklıkla viral etkenler ile oluşan infeksiyonlarda antibiyotikler çeşitli nedenlerle yanlış kullanılmakta ve antimikrobiyal direnç gelişimine neden olmaktadır. Çoklu ilaç dirençli suşların oluşumu ve bu etkenlere bağlı gelişen infeksiyonlar günümüzde en önemli halk sağllğ oluşturmaktadır. Antimikrobiyal ilaçların akılcı ve uygun şekilde kullanımı bu ilaçlara karşı direnç gelişimini önlemede en önemli stratejilerden birini oluşturmaktadır.

Anahtar sözcükler: Antibiyotik, akılcı antibiyotik kullanımı, antibiyotik direnci

\begin{abstract}
A significant part of the prescriptions of systemic antibiotics are made in patients who are treated in the outpatient setting. Although most outpatient respiratory tract infections that are caused primarily by viral pathogens do not require antimicrobial drug therapy, antibiotics are frequently prescribed. Inappropriate use of antibiotics is one of the most important factor affecting development of resistance to antimicrobial agents. The emergence of antibiotic resistant bacteria is a major public health problem throughout the world and rational use of antibiotics is therefore a very important. Strategy in preventin resistance against antibiotics.
\end{abstract}

Keywords: Antibiotic, rational antibiotic use, antibiotic resistance

Geliş tarihi/Received: 06 Ekim 2011; Kabul tarihi/Accepted: 04 Nisan 2012

*Iletişim adresi:

Dr. Mustafa Gökhan Gözel, İnfeksiyon Hastalıkları ve Klinik Mikrobiyoloji Anabilim Dalı, Cumhuriyet Üniversitesi Tıp Fakültesi, TR-58140 Sivas. E-posta: mggozel@yahoo.com

\section{Giriş}

Antibiyotiklerin keşfi ve bunların geliştirilmesi, geçen yüzyıldaki en önemli halk sağlığı uygulamalarından biri olarak geniş bir şekilde kabul görmüştür. 2007'de British Medical Journal tarafından yürütülen '1840'dan beri en önemli tıbbi gelişmeler nelerdir?' konulu ankette antibiyotikler ikinci sırada yer almıştır. Sayısız yaşam antibiyotiklerin kullanılması sayesinde korunmuş, cerrahi tekniklerde ve kanser tedavisindeki gelişmelerde oldukça kritik bir rol almıştır. Bununla birlikte bu etki çok önemli iki nedenle dramatik bir şekilde azalmıştır. Birincisi antimikrobiyal direncin artması, ikincisi ise antibiyotiklerin geliştirilmesi trendinin belirgin bir şekilde azalmasıdır [1, 2]. Son 20 yılda antibiyotik direnci en önemli halk sağlığı problemlerinden birini oluş̧urmuş̧ur. Çoklu ilaç direnci olan bakteriyel klonların ulusal ve uluslar arası düzeyde yayılımı, ilaç endüstrisinin araştırmalarını ve yeni antibiyotiklerin geliştirilmesine olan ilgiyi azaltııışır [3].

Antibiyotikler Türkiye'de en sık, dünyada ise kardiyak ilaçlardan sonra en sık kullanılan 
ilaçlardır. Bu yüksek kullanım oranları nedeni ile antibiyotik reçete edilmesi 'rasyonel antibiyotik kullanımı' başlı̆̆ altında kılavuzlarda konulmuş kurallarla takip edilmektedir [4]. Aşırı ve uygunsuz antibiyotik kullanımı oldukça önemli istenmeyen sonuçlara neden olmaktadır. Morbidite ve mortaliteyi arttırmakta, ilaç ilişkili yan etkilere, hastanede yatış süresinin uzamasına, dirençli mikroorganizmaların oluşmasına neden olmakta ve tedavi maliyetlerini arttırmaktadır [5-7]. Uygunsuz antibiyotik kullanımı antibiyotiklerin serbestçe ulaşılabileceği marketlerin olması ve spesifik infeksiyonların daha sıklıkla görülmesi nedeni ile özellikle gelişmekte olan ülkelerde yaygın olarak görülmektedir [4, 8].

Yeni antimikrobiyal ajanların araştırılması ve geliştirilmesindeki sorunlar 2004'de Infectious Diseases Society of America tarafından ayrıntılı bir şekilde açıklanmıştır. En önemlisi kronik hastalıklar için kullanılan ilaçlar ile karşılaştırıldığında antimikrobiyal ilaçların geliştirilmesi araştırmalarının karlılığının oldukça düşük olmasıdır. Kronik hastalıklarda kullanılan ilaçlardan farklı olarak, kaçınılmaz olan direnç gelişimini olabildiğince ertelemek için, iyi niyetli klinisyenler ve antibiyotik kullanım politikaları oluşturanlar tarafından yeni antibiyotikler sıklıkla en son başvurulan ilaçlar olarak önerilmektedir. $\mathrm{Bu}$ ilaçlar ayrıca oldukça kısa süreler için (ortalama 5-14 gün) kullanılmaktadır. Bu faktörlere rağmen özellikle Amerika'da National Institute of Allergy and Infectious Diseases (NIAID) tarafından dirençli bakterilere karşı tedavi geliştirilmesi için oldukça büyük miktarlarda finansman desteği sağlanmaktadır. Bununla birlikte, en iyi senaryo ile bu yeni antimikrobiyal ajanların kullanıma girmesi bir dekad ve hatta bazen daha da uzun zaman almaktadır $[9,10]$.

$\mathrm{Bu}$ bilgiler 1şığında kaçınılmaz olan direnç gelişimini geciktirmek ve eldeki mevcut antibiyotiklerin etkinliğini kaybetmeden daha uzun süre kullanılmasını sağlamak için, antibiyotiklerin akılcı ve uygun kullanımının teşvik edilmesi ve geliştirilmesi en önemli halk sağlığı koruma stratejilerden birini oluşturmaktadır.

\section{Antimikrobiyal tedavi genel özellikleri}

Akılc1 ve uygun antibiyotik kullanımının amac1; yan etki profili en az olan en uygun antibiyotiğin seçilmesi ve önerilen sürelerde kullanılması ile infeksiyonun tedavi edilmesi veya önlenmesidir.

\section{Antimikrobiyal ajan seçiminin genel özellikleri:}

- Klinik etkinlik, göz önünde bulundurulması gereken en önemli etmendir.

- Antimikrobiyal ajan, bilinen veya şüphelenilen patojenlere ve bu patojenlerin duyarlılık durumlarına göre seçilmelidir.

- Etkinliği kanıtlanmış alternatif diğer ajanlar göz önünde bulundurulmalıdır.

- İlaç yan etkileri, hastanın klinik durumu ve ek hastalıkları (gebelik, immunsüpresyon veya böbrek yetmezliği gibi) mutlaka değerlendirilmelidir.

- Hasta uyumunun düzeyi göz önünde bulundurulmalıdır.

- İlacın etkinliği ve toksisitesi değerlendirildikten sonra maliyet mutlaka göz önünde bulundurulmalıdır [11].

Antimikrobiyal ajanlara karşı bakteriyel direnç artışı en önemli halk sağlığ tehditlerinden birini oluşturmaktadır. Antibiyotik kullanımının bu probleme katkıda bulunan en önemli faktör olduğu kabul edilmektedir. Dirençli mikroorganizmaların oluşumunu ve yayılımını azaltacak ajanlar tedavide seçilmelidir. Aynı zamanda birçok çalışmada antibiyotiklerin insan mikrobiyolojik flora üzerine negatif etkide bulunarak sağlık üzerine zararlı etkilerinin olduğu belirtilmiştir. Bu nedenlerle akılcı ve uygun antibiyotik kullanımın ve antibiyotik kullanımının kısıtlanmasının önemi giderek artmaktadır [11, 12].

\section{Antibiyotik aşırı kullanımını etkileyen faktörler}

Sistemik antibiyotiklerin yaklaşık olarak \%80'i birinci basamak sağlık kuruluşlarında kullanılmaktadır. En önemli endikasyonu ise solunum yolu infeksiyonlarıdır [13]. Her yıl 
ayaktan başvuran ve antibiyotik kullanan hastaların yaklaşık \%75'ini akut solunum yolu infeksiyonları oluşturmaktadır [14]. Bazı solunum yolu infeksiyonları (kronik bronşit akut alevlenmesi, akut otitis media ve akut bakteriyel rinosinüzit vb.) antibiyotik tedavisi gerektirmesine rağmen, toplumda gelişen solunum yolu infeksiyonlarının çoğunda (akut bronşit, nazal farenjit/soğuk algınlığı ve non-spesifik üst solunum yolu infeksiyonları vb.) etken solunum yolu virüsleridir ve antibiyotik tedavisi gerektirmemektedir $[15,16]$. Amerika'da sadece 1992 'de yetişkin hastalara 57 milyon antibiyotik reçete edildiği ve bunların 12 milyonunun soğuk algınlığı, ÜSYE ve bronşit için olduğu tespit edilmiştir. Viral infeksiyonu olan yetişkin hastaların neredeyse yarıya yakını antibiyotikler ile tedavi edilmekte ve sonuç olarak antibiyotiklerin aşırı kullanımına neden olmaktadır [17].

Antibiyotikler sıklıkla ampirik olarak kesin bir bakteriyel infeksiyon tanısı olmaksızın başlanmaktadır. $\mathrm{Bu}$ durum özellikle boğaz ağrısı, akut öksürük, üriner sistem infeksiyonları ve bazı ishal vakalarında görülmektedir [18]. Uygunsuz antibiyotik kullanımı ile ilişkili çeşitli faktörler bulunmaktadır. Hekimin yeterli zamanının olmamasının yarattığ bask1, hastanın beklentisi ve uygun olmayan savunmacı tıbbi yaklaşım bu faktörler arasındadır [18, 19]. Birçok hasta hekime antibiyotik yazılması beklentisi ile başvurmaktadır. Bunun sonucunda hekim hastayı memnun etmek, iyi bir hasta-hekim ilişkisi oluşturmak ve bunu korumak için antibiyotik reçete edilmesi konusunda bir baskı hissedebilmektedir. Antibiyotik reçete edilmesi hastada benzer durumlarda antibiyotik garanti algısına neden olmakta ve benzer şikâyetlerin oluşması halinde antibiyotik ihtiyacı hissederek aynı hekime başvurma eğilimi oluşmaktadır. Özellikle viral infeksiyonlardan şüphelenilmesi halinde antibiyotiklerin her zaman gerekli olmadığı konusunda olguyu bilgilendirmek için zaman harcamak yerine klinisyenler, antibiyotik reçete edilmesini hastayı hızl bir şekilde tedavi etme yolu olarak görebilmektedir. Ayrıca hekimler, bakteriyel infeksiyonu olan olgular için antibiyotik reçete etmemenin neden olacağı potansiyel sekellerden kaçınmak için savunmacı bir tıbbi yaklaşımla antibiyotik reçete edebilmektedirler [18, 20-22].

Kotwani ve ark. [23], birinci basamak sağlık kuruluşunda çalışan doktorların en sık antibiyotik reçete etme nedenlerini hastalığın tanısında belirsizlik, hastanın istek ve beklentileri, doktorun hastayı kaybetmemek istemesi ve başka bir başvuruda kendisinin tercih edilmesi isteği, ilaç şirketlerinin temsilcilerinin etkisi ve yaşam koşullarındaki hijyen şartlarının kötü olması nedeni ile toplumun fakir kesiminde yaşayanlarının antibiyotiğe ihtiyacı olması gibi bir izlenime sahip olması olarak saptamışlardır.

Gelişmekte olan ülkelerde halkın büyük bir çoğunluğu sanitasyon ve beslenme şartlarının oldukça zayıf olduğu alanlarda yaşamakta ve infeksiyonlar sıklıkla görülmektedir. Birinci basamak sağlık kuruluşlarına ulaşmada eksiklik ve kişilerin kendi kendine antibiyotik almaları oldukça yaygın olarak görülmektedir. Hekim açısından bakıldığında ise, hasta hekim ilişkisi için yeterli zaman olmaması, laboratuar ve radyolojik desteğin olmaması ve antibiyotik yazılması konusunda hasta baskısı uygunsuz yazılan reçetelere neden olmaktadır [11, 24].

Antimikrobiyal ilaçlar ya profilaktik ya da terapötik endikasyonlar için kullanılmaktadır. Yanlış endikasyon en önemli uygunsuz antibiyotik kullanımı nedenlerindendir. $\mathrm{Bu}$ nedenle doktor tedavinin nedenlerini ve gereksinimlerini iyi açıklamalı, altta yatan hastalık öyküsü, yaş, immünsüpresyon varlığı, klinik durumun ciddiyeti ve seyahat öyküsünü mutlaka değerlendirmelidir [25].

\section{Akılcı antibiyotik kullanımının geliștirilmesi}

Center for Diseases Control and Prevention (CDC), klinisyenlerin, viral solunum yolu infeksiyonların bakteriyel solunum yolu infeksiyonlarından ayırt edebilirlerse yılda yaklaşık olarak 50 milyon antibiyotiğin reçete edilmesini önleyebileceklerini belirtmiştir. Bununla birlikte klinisyen için öksürük, nazal konjesyon, postnazal akıntı, sinüsler üzerinde basınç, ağrı ve ateş şikâyetleri ile başvuran bir hastada viral ya da bakteriyel ayrımını yapmak oldukça güç olabilmektedir [26, 27]. Solunum yolu infeksiyonu belirti 
ve bulguları olan hastalarda bakteriyel infeksiyonun tanısı doğru konulduğunda akılc1 antibiyotik kullanımı temel ilkelerinden biri yerine getirilmektedir. Bu infeksiyonların birçoğu bakteri dişı nedenlerle oluşmakta ve antibiyotik tedavisi gerektirmemektedir [28]. Hasta başı uygulanan testler veya elektronik raporlama ile daha hızlı sonuçlanan laboratuar testleri antimikrobiyal ajanların daha doğru bir şekilde kullanılmasına katkıda bulunabilir [29].

Kişisel alışkanlıkları değiştirerek uygun antibiyotik kullanımının arttırılmasında klinik kılavuzların kullanımı etkili olabilmektedir. Etkinliğini ve kullanılabilirliğini arttırmak için antibiyotik kullanım kılavuzları kanıta dayalı olmalı, ayrıca genel direnç verilerinin yanı sıra lokal direnç paternleri hakkında da tanımlayıcı olmalıdır. $\mathrm{Bu}$ yüzden lokal uygulamalara çabuk ve kolay adapte edilebilen kılavuzlar kullanılmalıdır. Örneğin solunum yolu infeksiyonları için hazırlananları viral hastalık için antibiyotik kullanımının önüne geçebilmeli, tanısal kriterlerin ana hatlarını vermeli ve etkisiz antimikrobiyal ajan kullanımını önlemelidir [15, 30].

Klinik kılavuzların kullanımında birçok problemin olduğu bazı çalışmalarda gösterilmiştir. Örneğin klinisyenler, mevcut kılavuzların varlığının farkında olamayabilmekte veya kılavuz önerilerini nasıl uygulayacağı konusunda yeterince deneyim sahibi olamayabilmektedir. Ayrıca, klinisyenler kılavuzların bazı ya da tüm önerilerine katılmamakta, bakış açısını reddedebilmektedir. Bütün bu sorunların üstesinden gelmek için, kontrol listeleri veya hatırlatma sistemleri kullanımı gibi kılavuzlara uyumu arttırmayı amaçlayan yöntemler ve eğitim uygulamaları önerilmektedir [15, 31]. Antibiyotik kontrol programlarının olmazsa olmazı eğitimdir. Klinisyenlerin hala antibiyotikler konusunda bilgi eksiklikleri olabilmektedir. $\mathrm{Bu}$ eğitimler özellikle tıp öğrencilerine ve hekimlik mesleğine yeni adım atan birinci basamak sağlık kurumlarında görev alanlara yönelik olmalıdır [11, 32].

Yazılı eğitim materyallerinin kullanımı veya kendi kendine geri bildirim yöntemi kullanılması hekimin uygun antibiyotik kullanımı konusundaki yaklaşımında ya değişikliğe neden olmamakta ya da sınırlı düzeyde değişikliğe neden olmaktadır. İnteraktif eğitim toplantıları didaktik derslerle karşılaştıııldığında daha etkili olmaktadır. Hasta odaklı uygulamalardan biri olan "gecikmiş antibiyotik reçete edilmesi" etkili bir şekilde antibiyotik kullanımını azaltmıştır. $\mathrm{Bu}$ yöntemde doktor hastaya ilk başvurusundan birkaç gün sonra antibiyotik reçete etmekte, bu süre içerisinde hastalık belirtileri kendiliğinden gerilemekte ve hasta antibiyotik ihtiyacı duymamaktadır. $\mathrm{Bu}$ yöntem eğer ciddi bir infeksiyon şüphesi yoksa uygulanabilir bir yöntem olup, mortalite artışı ile sonuçlanmadığı gösterilmiştir. Doktoru, hastayı ve halk eğitimlerini içeren çeşitli mekânlardaki ve biçimlerdeki çok boyutlu interaktif eğitim uygulamaları uygunsuz endikasyonlarda yazılan antibiyotik reçete edilmesini en etkili şekilde azaltan yöntemdir $[33,34]$. Hastalara ve uygulayıcılara yönelik eğitim çalışmaları ile uygun antibiyotik kullanımın arttırılmasında başarı sağlandığı gösterilmiştir $[15,35]$.

Hasta beklentisi, uygunsuz antibiyotik reçete edilmesi nedenlerinden birini oluşturmaktadır. Tonsillit nedeni ile antibiyotik reçete edilen bir hasta gelecekte oluşacak benzer şikâyetlerde aynı doktoru ziyaret etme eğiliminde olmaktadır. Hasta eğitim materyalleri ile hasta için hazırlanan broşürlerin kullanımın antibiyotik beklentisini azaltabileceği gösterilmiştir. Polikliniklerde bu eğitim materyallerinin ve broşürlerin kullanılması desteklenmelidir [18, 36].

Antimikrobiyal tedavinin amacına ulaşması için ayrıca uygun dozda ve sürede tedavi verilmelidir. Sistemik olarak verilen antibiyotik infeksiyon bölgesindeki mikroorganizmaları öldürecek veya inhibe edecek yeterli konsantrasyona ulaşmalıdır. İlaç eliminasyon yarı ömürleri göz önünde bulundurularak doz aralıkları ayarlanmalı ve infeksiyon tipi ve yerine göre önerilen sürelerde tedavi planlanmalıdır [25]. Araştırmalarda antibiyotiklerin uygun şekilde kullanıldığında solunum yolu infeksiyonlarına neden olan bakterileri eradike etmede etkili olduğu ve infeksiyon 
bulgularının hızla gerilemesini sağladığı gösterilmiştir [27, 37].

Antibiyotikler günümüzde kullanılan en etkili ilaçlardandır ve şüphesiz toplum sağlığının iyileştirilmesi için oldukça önemli katkılarda bulunmaktadır. Antibiyotiklerin doğru kullanımı, gelecekte de etkinliğinin devam etmesini sağlamada oldukça önemlidir [13]. Temel temizlik ve sanitasyon önlemlerinin geliştirilmesi, ilaç seçimi, dozu ve tedavi süresi konusunda antibiyotik tedavi stratejilerinin iyileştirilmesi ve antibiyotik kullanımının olabildiğince daha da azaltılması önem arz etmektedir [3]. Antibakteriyel direnç dünyadaki en önemli halk sağlığı sorunlarından birini oluşturmakta ve bu durumun gelişmesindeki en önemli neden antibiyotik kullanımının global olarak artışıdır [38, 39]. Randomize kontrollü çalışmalar ışığında kanıta dayalı olarak hazırlanan ve periyodik olarak güncellenen kılavuzların kullanımı oldukça önemlidir [11]. Üniversite düzeyinde tıp ve farmakoloji eğitimi, antimikrobiyal direnç tehdidi ve uygun antibiyotik reçete edilmesi konusuna daha büyük bir önem verilerek koordine edilmelidir. Lisansüstü düzeyde ilaç endüstrisi sponsorluğunda oluşturulan programlar sınırlandırılmalıdır. Profesyonel kurum ve topluluklar antimikrobiyal ilaç kullanımı ile ilgili eğitimleri ve uygulamaları üstlenmelidir [40, 41].

\section{Kaynaklar}

1. Ferriman A. BMJ readers choose the "sanitary revolution" as greatest medical advance since 1840. BMJ 2007; 334: 111.

2. Spellberg B, Powers JH, Brass EP, Miller LG, Edwars JE Jr. Trends in antimicrobial drug development: implications for the future. Clin Infect Dis 2004; 38: $1279-86$.

3. Molstad S, Erntell M, Hanberger H, Melander E, Norman C, Skoog G, Lundborg CS, Soderstron A, Torell E, Cars O. Sustained reduction of antibiotic use and low bacterial resistance: 10 year follow up the Swedish Strama programme. Lancet Infect Dis 2008; 8: 125-32.

4. Tunger O, Dinc G, Ozbakkaloglu B, atman UC, Umit Algun. Evaluation of rational antibiotic use. Int J Antimicrob Agents 2000; 15: 131-5.

5. Niederman MS. Principles of appropriate antibiotic use. Int J Antimicrob Agents 2005; $26: 170-5$.

6. Niederman MS. Appropriate use of antimicrobial agents: challenges and strategies for improvement. Crit Care Med 2003; 31: 608-16.

7. Garau J, Dagan R. Accurate diagnosis and appropriate treatment of acute bacterial rhinosinusitis: minimizing bacterial resistance. Clin Ther 2003; 25: 1936-51.

8. Tunger O, Karakaya Y, Cetin CB, Dinc G, Borand H. Rational antibiotic use. J Infect Dev Ctries 2009; 3: 88-93.

9. Infectious Diseases Society of America. Bad bugs, no drugs: As antibiotic discovery stagnates. A public health crisis brews. July 2004. Available at Retrieved http://www.fda.gov/ohrms/dockets/dockets/04s0233/04s-0233c000005-03-IDSA-vol1.pdf (Accessed on December 3, 2012).

10. Peters NK, Dixon DM, Holland SM, Fauci AS. The research agenda of the National Institute of Allergy and Infectious Diseases for antimicrobial resistance. J Inject Dis 2008; 197: 1087-93.

11. Güven GS, Uzun O. Principles of good use of antibiotics in hospitals. J Hosp Infect 2003; 53: 91-6.

12. Rautakorpi UM, Huikko S, Honkanen P, Klaukka T, Makela M, Palva E, Roine R, Sarkkinen H, Varonen H, huovinen P; MIKSTRA Collaborative Study Group. The Antimicrobial Treatment Strategies (MIKSTRA) program: a 5-year followup of infection-specific antibiotic use in primary health care and the effect of implementation of treatment guidelines. Clin Infect Dis 2006; 42: 1221-30.

13. Llor C, Cots JM, Gaspar MJ, Alay M, Rams N. Antibiotic prescribing over the last 16 years: fewer antibiotics but the spectrum is broadening. Eur $\mathrm{J}$ Clin 
Microbiol Infect Dis 2009; 28: 893-7.

14. McCaig LF, Hughes JM. Trends in antimicrobial drug prescribing among officebased physicians in the United States. JAMA 1995; 273: 214-9.

15. File TM Jr, Hadley JA. Rational use of antibiotics to treat respiratory tract infections. Am J Manag Care 2002; 8: 713-27.

16. Çağr1 Buke A, Ermertcan S, Hoşgör-Limoncu M, Çiçeklioğlu M, Eren S. Rational antibiotic use and academic staff. Int J Antimicrob Agents 2003; 21: 636.

17. Gonzales R, Steiner JF, Sande MA. Antibiotic prescribing for adults with colds, upper respiratory tract infections, and bronchitis by ambulatory care physicians. JAMA 1997; 278: 901-4.

18. Mcnulty CA. Optimising antibiotic prescribing in primary care. Int $\mathbf{J}$ antimicrob Agents 2001; 18: 329-33.

19. Briel M, Christ-Crain M, Young J, Schuetz P, Huber P, Périat P, Bucher HC, Müller B. Procalcitonin-guided antibiotic use versus a standard approach for acute respiratory tract infections in primary care: study protocol for a randomised controlled trial and baseline characteristics of participating general practitioners [ISRCTN73182671]. BMC Fam Pract 2005; 6: 34.

20. Ball P, Baquero F, Cars O, File T, Garau J, Klugman K, Low DE, Rubinstein E, Wise R; Consensus Group on Resistance and Prescribing in Respiratory Tract Infection. Antibiotic therapy of community respiratory tract infections: strategies for optimal outcomes and minimized resistance emergence. J Antimicrob Chemother 2002; 49: 31-40.

21. Larrabee T. Prescribing practices that promote antibiotic resistance: strategies for change. J Pediatr Nurse 2002; 17: 126-32.

22. Gonzales R, Bartlett JG, Besser RE, Cooper RJ, Hickner JM, Hoffman JR, Sande MA. Principles of appropriate antibiotic use for treatment of acute respiratory tract infections in adults: background, specific aims, and methods. Ann Intern Med 2001; 134: 479-86.

23. Kotwani A, Wattal C, Katewa S, Joshi PC, Holloway K. Factors influencing primary care physicians to prescribe antibiotics in Delhi India. Fam Pract 2010; 27: 684-90.

24. Cadieux G, Tamblyn R, Dauphinee D, Libman M. Predictors of inappropriate antibiotic prescribing among primary care physicians. CMAJ 2007; 177: 877-83.

25. Pillai SK, Eliopoulos GM, Moellering RC. Principles of Anti-infective Therapy. In: Mandell GL, Douglas RG, Dolin R, Eds. Principles and Practice of Infectious Diseases, 7th ed. Philadelphia, Penn: Churchill Livinstone 2009; 267-78.

26. Dowell SF, Schwartz B, Phillips WR. Appropriate use of antibiotics for URIs in children: Part II. Cough, pharyngitis and the common cold. The Pediatric URI Consensus Team. Am Fam Physician 1998; 58: 1335-42.

27. Gwaltney JM Jr. Acute community-acquired sinusitis. Clin Infect Dis 1996; 23: 1209-23.

28. Fendrick AM, Saint S, Brook I, Jacobs MR, Pelton S, Sethi S. Diagnosis and treatment of upper respiratory tract infections in the primary care setting. Clin Ther 2001; 23: 1683-706.

29. Kolmos HJ, Little P. Controversies in management: should general practitioners perform diagnostic tests on patients before prescribing antibiotics? $\mathrm{Br}$ Med $\mathrm{J}$ 1999; 318: 799-802.

30. Grimshaw JM, Russell IT. Effect of clinical guidelines on medical practice: a systematic review of rigorous evaluations. Lancet 1993; 342: 1317-22.

31. Cabana MD, Rand CS, Powe NR, Wu AW, Wilson MH, Abboud PA, Rubin HR. Why don't physicians follow clinical practice guidelines? A framework for improvement. JAMA 1999; 282: 1458-65.

32. Şahin H, Arsu G, Köseli D, Büke C. Evaluation of primary health care physicians' knowledge on rational antibiotic use. Mikrobiyol Bul 2008; 42: 343- 
8.

33. Arnold SR, Straus SE. Interventions to improve antibiotic prescribing practices in ambulatory care. Cochrane Database Syst Rew 2005; 19: Cd003539.

34. Davis DA, Thomson MA, Oxman AD, Haynes RB. Changing physician performance. A systematic review of the effect of continuing medical education strategies. JAMA 1995; 274: 700-5.

35. Buke C, Hosgor-Limoncu M, Ermertcan S, Ciceklioglu M, Tuncel M, Köse T, Eren S. Irrational use of antibiotics among university students. J Infect 2005; 51: 135-9.

36. Macfarlane JT, Holmes WF, Macfarlane RM. Reducing reconsultations for acute lower respiratory tract illness with an information leaflet: a randomized controlled study of patients in primary care. Br J Gen Pract 1997; 47: 719-22.

37. Gwaltney JM Jr, Scheld WM, Sande MA, Sydnor A. The microbial etiology and antimicrobial therapy of adults with acute community-acquired sinusitis: a fifteen-year experience at the University of Virginia and review of other selected studies. J Allergy Clin Immunol 1992; 90: 457-61.

38. Goossens H, Ferech M, Vander Stichele R, Elseviers M; ESAC Project Group. Outpatient antibiotic use in Europe and association with resistance: a crossnational database study. Lancet 2005; 365: 579-87.

39. Rossignoli A, Clavenna A, Bonati M. Antibiotic prescription and prevalence rate in the outpatient paediatric population: analysis of surveys published during 2000-2005. Eur J Clin Pharmacol 2007; 63: 1099-106.

40. Hsu LY, Kwa AL, Lye DC, Chlebicki MP, Tan TY, Ling ML, Wong SY, Goh LG. Reducing antimicrobial resistance through appropriate antibiotic usage in Singapore. Singapore Med J 2008; 49: 749-55.

41. Öztürk İI, Avci İY, Coşkun Ö, Gül HC, Eyigün CP. Birinci Basamak Sağlık Kuruluşunda Görev Yapan Hekimlerin Sik Görülen Toplum Kaynaklı Enfeksiyonlardaki Antibiyotik Seçimleri ve Bunu Etkileyen Faktörler. Firat Tıp Dergisi 2008; 13: 255-60. 